Rupantaran : A Multidisciplinary Journal

Vol. III : 51-61, March, 2020

ISSN : 2091-0061

Research Management Cell (RMC)

Dhankuta Multiple Campus, Dhankuta

Tribhuvan University, Nepal

\title{
Rethinking Population Policies from Family Planning to Population Management
}

\author{
Kewal Ram Parajuli ${ }^{1}$ \\ Email: parajulikr80@gmail.com
}

\section{Abstract}

Population policy plays a significant role for the desired demographic and social outcome of a nation with aims of social welfare and progress. Basically, antinatalist and pronatalist policies are adopted to influence fertility. Family planning programs and policies have been initiated with the aim of population management in Nepal but concentrated on fertility reduction in a later period, the continuation of such policies and rapid decreasing of fertility may create tribulation in future as developed countries with having a condition of depopulation.

This paper attempts to analyze content related to fertility and family planning policies and activities thoroughly and the level, trend, and projection of fertility and family planning with the objective of finding future implications. Findings suggest that it should focused on population responsive policies, quality life of people, utilization of demographic dividends mostly on population management rather than anti-natalist population policy. Since a long time, Nepal has adopted the Anti-natalist population policy, which should be rethought for the sustainability of development and population management. Fertility, a major process of population increase, Basically, determined by many biological, sociocultural, economic, geographical factors, can't increase as the nation's desire and need. So, need to pay attention to prevent depopulation status. Keywords: Fertility, family planning, policies, demographic dividend

\section{Introduction}

Policies play very significant roles to achieve desired socio-economic and demographic progress. It is necessary to study the contribution of the population in formulating population policies and programmes. There is a two-way relationship between determinants of population and population policies. Fertility, mortality, and migration like major population components are also guided through population

1. Mr. Parajuli is a Lecturer of Population Education at Tribhuvan University, Dhankuta Multiple Campus, Dhankuta. 
policies and programmes. The population situation, context of country and need are the basic determinants of a particular population policy. Appropriate population policy and programmes can bring eventful change in civic life with contributing prosperity of the nation. Population policy is taken broadly or comprehensively in the sense of including all efforts to bring change in the existing population structure. Population policy may be defined as deliberately constructed or modified institutional arrangements and/or specific programs through which governments influence, directly or indirectly, demographic change (Demeny, 2003). According to Frank Notestein, the main objective of population policy today is to ensure that there is a reasonable gap between the fall of death rates and birth rates (Dasgupta, 2012). Population policy is taken as a deliberate effort by a national government to influence the demographic variables like fertility, mortality, and migration (Organski \& Organski, 1961). Population policy can be implicit or explicit, long term or short term on the basis of its nature accordingly human welfare, quality of life and sustainability of development are key target areas of population policy.

Population policies have a long history in human society since the time of ruler or government. As their requirement, they tried to manage the population for war, strength, invade, etc. Among the major three key components of population migration and fertility are focused on population policy than mortality because death is highly associated with health policy and programmes. Fertility, an actual reproductive performance responsible to increase population, is determined by many socio-economic and cultural factors. Bongaarts (1978) showed a relationship among the determinants of fertility through indirect to direct (proximate) on the pioneering work of Davis and Blake. Which, has included contraception and induced abortion as deliberate marital fertility control factors. The impact of decline fertility is quite different than mortality and migration because it creates a long-term effect on age structure with age after age. From the population management perspective, two types of fertility policies are existing in the world as pronatalist and anti-natalist. Both types of policies are in practice in world. Fertility is an individual and couple-based performance which is influenced by many socio-cultural norms and values, economic status so efforts of the government are not only sufficient for management of fertility. Countries which are in highly developed stage and facing the problem of depopulation are trying to adopt pronatalist population policies with the low achievement of targets and least developed countries are focusing on anti-natalist population policies with family planning programmes have successive outcomes except some countries. Contraception is taken as the intermediate fertility variable primarily responsible for the wide range in the levels of fertility within marriage by Bongaarts. Through the influence of a pessimistic view on rapid population growth, it has been tried to control sharply after world war II (Baby boom period). The inverse relationship between population and resources was kept in mind by most of the developed countries and 
focused on birth control, ultimately means and methods of family planning became key instruments to control the population world widely. Most of the developing nations became the target areas of population control which had a high fertility rate. In this context family planning programs and policies have been started from the second development plan (1963-1965) in Nepal. The family planning program was introduced with the objective of balancing population growth and economic growth (Tuladhar 1989). Family planning is defined by WHO as "a way of thinking and living that is adopted voluntarily upon the basis of knowledge and attitudes by individual and couples for promoting health and welfare of the family, which ultimately supports social development of the nation" (Dixit \& Bandhani, 2019). Family planning objectives are concentrated on small family norms, the wellbeing of a family with respecting individual and couple's health rights. Norms focused on the small family has created significant change in fertility behavior of people, in this regard future population size, growth and structure should attentive area for policymakers. Is there a correct policy track for the wellbeing of people in the present and future or not? necessary to find through the review of existing fertility and family planning policies and achievement of Nepal.

\section{Methods and Materials}

This article is based on secondary data sources and research design is descriptive, analytical and explanatory in nature. Published national and international journal articles, reports, plan documents, books are collected to review literature, content analysis. Data from UN, National Census and Nepal Demographic Health Survey (NDHS) are used to show basic demographic trends and projection of Nepal with aiming to aware of relevant future fertility and family planning policies for Nepal.

\section{Results and Discussion}

In the context of Nepal, most of the population policies are guided and included in the periodic developmental plan. Population issues and concerns are tried to address through different strategies, policies, and programmes since 1956. To influence fertility family planning programmes are launching for a long time in the context of Nepal.

\section{Fertility and family planning in the periodic development plan}

Nepal has started a periodic plan since 1956, from that point of time population redistribution from densely Hill towards Terai region Programme has been started. At that period the Family Planning Association of Nepal (FPAN) was established. The family planning programme was accepted at a policy level in the second plan (1963-1965). Formally population policy started from the third plan (1965-1970) the objective was to bring about a reduction in the crude birth rate (CBR). Nepal Family Planning, Maternal and Child Health (FPMCH) Board was also established under the Ministry of Health At that period. The fourth plan (1970-1975) suggested two ways 
to reduce birth rate as bringing changes in socio-economic conditions and cultural practices of people and implement family planning programmes at different levels. Targets for different levels of family planning were also set. A task force was formed in 1974 to prepare a population policy document for Nepal and the task force prepared a population policy document that covered major three areas fertility, mortality and migration. In a fifth plan (1975-1980) a high-level Population Policy Coordination Board (POPCOB) was formed (August 1975) to coordinate and implement policy in a proper way. It envisaged to reduce birth rate and various demographic targets were set. The Vital Registration System was introduced as a pilot project with the assistance of UNFPA. Population Policy Coordination Board was constituted. Later, it developed as National Commission on Population (NCP). In the sixth plan (1980-85), National Population Commission developed a National Population Strategy, approved by the government of Nepal. This strategy contained both short term and long-term strategies. Major policy goals were to reduce TFR from 6.3 to 5.8 by the year 1985, to 4.0 by the year 1990 and to 2.5 by the year 2000 . This plan aimed at reducing the population growth rate of 2.6 percent to 2.2 percent by the year 1985 to 1.6 percent in 1990 and 1.2 percent in the year 2000. Seventh plan (1985-1990) attached Maternity and child welfare programmes with family planning services in order to control population growth in accordance with national policies and long-term goals set by NPC. Objectives were to control population growth in a planned way. Priority was given for the unmet needs of family planning and weak status of women. The balance between population growth and socio-economic development was focused in the eighth plan (1991-1996). The effort was to control the population by making mother and child health and family planning services effective. Revised targets were to reduce TFR from 5.8 to 4.5 and to reduce maternal mortality from 850 to 720 . International Conference on Population and Development (ICPD) 1994 and establishment of the Ministry of Population and Environment (1995) started to play a role in policy and programmes. The reproductive right was established as a part of human right. Ninth plan (1997-2002) was a part of a 20 years long term plan. Population management was taken as one of the major sectors of development thrust. The long-term objective of reducing the total fertility rate to the replacement level within the 20 years has been adopted. The objectives of the Ninth Plan were to attract couples towards twochild family norms, to implement various programmes to bring down the fertility rate to replacement level within 20 years and to make quality family planning and maternal-child health services easily accessible and available. Specific targets were to reduce TFR to 4.2, which was achieved as targeted and reached to 4.1 in 2001 and to increase Contraceptive Prevalence Rate up to $37.0 \%$. Ninth plan commitments were renewed in the tenth plan (2002-2007). Population issues were incorporated into the total development process and focused on behavioral change for accomplishing the demographic targets. Long term concept was to achieve the replacement level 
of fertility by 2017 and to contribute towards poverty alleviation through educated, healthy and skilled human resource development for having a prosperous society. To relate people into development activities through the development of small and quality family was an objective. TFR target was 3.5 and 3.6 per woman as expected and normal and CPR target was $47 \%$ and $46 \%$ as an expected and normal. Access and quality of family planning services and other indirect measures were included for the reduction of fertility. Three year's interim plan (2007/08-2009/10) included the issue of promoting reproductive health rights for both males and females. Policy and strategies were attached to Millennium Development Goals (MDG) and Population Perspective Plan. Youth (10-24) were identified as the target group, small and quality family life and family planning programme was focused on mobilizing all agencies. The next three years interim plan (2010/11-2012/13) kept integration of population management to socio-economic development and to reduce fertility to replacement level by 2022 through all group's participation as major objectives. Activities to facilitate the demographic transition by mainstreaming population in all sectors and aspects of development with doorstep service through one door system and decentralization were focused. Mutual management of human resources with population management was a strategy of the plan. IEC and intensive RH service were focused. To reduce TFR from 3.1per woman to 2.75 per woman and to increase CPR from $48 \%$ to $57 \%$ were quantitative targets. The Thirteenth plan (2013/14-2015/16) took population management and quality of life as major aspects. Reproductive health was taken as a human right. Population and development integration were taken as strategies. The concept of Sustainable development was integrated with population management. Most of the policies were the same as the previous plan. Targets for CPR was $67 \%$ and for TFR 2.5 per woman.

Improvement of quality life through the balance of population, environment, and development was the major aim of the fourteenth plan (2016/17-2018/19). It focused on the balance between population and socio-economic development with the implementation of population management and reproductive health programmes. The population was taken as an integral part of the development with coordinating related agency was the strategy. Promotion small and quality family, use of contraceptives and reproductive health-related awareness were focused along with adolescents and information management related to population. There were no specific targets related to fertility and contraceptive use. The fifteenth plan (2019/20-2023/24) focused on migration, urbanization management, and utilization of demographic dividend. Adolescent's safe sexual behavior, reproductive health service is taken as a right based programme. Programmes based on ethnic inclusion, senior citizens, population management information systems (PMIS) are major aspects. The expected TFR is 2.1 as replacement level. 
Population issues are associated with multiple social sectors, in the context of Nepal separate Population Policy was not formulated at the initial phase of the development plan. Most of the issues were incorporated in a periodic plan. From the First Five-year Plan to the Fifth Plan, the emphasis was on migration, family planning, and maternal-child health programme. Population distribution and migration management issues were incorporated by the sixth plan, the Seventh Plan was attached to population reduction through family planning. The eighth plan focused on the reduction of fertility rate through integration it with development, at the same time ICPD 1994 held and MoPE 1995 was established. The Ninth Plan was associated with the twenty-year long-term perspective, CPR increment, fertility reduction upto replacement level. Small and quality family, healthy manpower development, the balance between population and development were the incorporated issues by the tenth plan. Long term concept was to achieve the replacement level of fertility by 2017. From the fourteenth plan, no specific objective and policies are for fertility reduction and CPR increase.

Population Perspective Plan (2010-2031): It was first conceived in the ninth five-year plan (1997- 2002 in response to reduce fertility to replacement level and alleviating poverty. That was attached with a long-term policy. The tenth plan (20022007) advanced the concept of long-term population policy. Similarly, it was based on the Poverty Reduction Strategy Paper (PRSP). As the supporting document of ICPD-1994, Beijing Conference-1995 and Copenhegen Conference 1996 aims it has incorporated various sectors associated with population development and quality life. Internalization of population issues with each development activity and to facilitate demographic transition through all possible ways with coordination form related agencies and monitoring were the main objectives. It has projected major socio-economic and the demographic indicators up to the year 2031. To provide family planning services to the community level with coordinating private and nongovernmental sectors, focusing on adolescent's reproductive health and adolescent's friendly environment, safe motherhood and promotion of small family were the programmes/activities. (PPP, 2010-2031)

National Working Policy of Family Planning Services, 2068: It was carried for the implementation of international commitments and Nepal Health Sector ProgramImplementation Plan II 2010-2015. Which has focused on unmet needs of family planning services and services for remote rural areas. Increasement of access and use of Safe, effective and quality family planning services Especially to remote rural, marginalized and back-warded communities was the major objective. It has been targeted TFR 2.5 and CPR 67\% up to the year 2015. Male participation on reproductive health, management of unmet needs and service provider, improvement of access and availability of services, and establishment of family planning as reproductive rights 
were the major policy area of working policy (National Working Policy of Family Planning Services, 2068).

National Population Policy 2071: Prevalence of child marriage, high fertility rate, early age at pregnancy and shorter child spacing, lack of demand for, and the lack of capacity to use contraceptives, etc. were taken as reproductive and maternal healthrelated population problems. Create a situation to accept the marriage, need and use of contraceptive, pregnancy, fertility and reproductive health as the rights of citizen were taken as challenges (National Population Policy 2071). To bring about quality changes in the lives of all citizens by integrating population issues with development, ensuring fundamental rights related to reproduction and reproductive health was taken as aims in NPP, 2071 and major demographic indicators for the year 2090 (2034 AD) targeted. Expected TFR was 2.1 per woman and the annual population growth rate is $1.1 \%$ for the year 2090. Sexual health, family planning and safe abortion including reproductive health related services was aimed to develop as right based programme. National Population Strategy, 1983, National Health Policy 2071 and other healthrelated programmes and projects played a significant role in reduction of fertility and increment of CPR.

\section{Fertility and family planning related achievement}

Crude Birth Rate (CBR): As a major component of population dynamics, it was a major targeting area for most of the plans and policies. It has been tried to reduce as per the intention of the international community or by fear of population explosion by a government officials. Since the date 1981 to 2019 it has been significantly reduced by more than $50 \%$. CBR has been reduced with a high digit (5.5) between the survey 2001 and 2006 and the period 1986 to 1991 it seems increased by around 1 digit instead of decreasing.

Table 1: Trends Crude Birth Rate (CBR, 1981-2019)

\begin{tabular}{|c|l|r|r|}
\hline SN & \multicolumn{1}{|c|}{ Source } & \multicolumn{1}{|c|}{ Date } & \multicolumn{1}{c|}{ CBR } \\
\hline 1 & CBS (Census Data) & 1981 & 44.0 \\
\hline 2 & Nepal FP/MCH Project, MOH & 1981 & 42.9 \\
\hline 3 & CBS Demographic Sample Survey & 1986 & 40.7 \\
\hline 4 & CBS (Census Data) & 1991 & 41.6 \\
\hline 5 & Nepal Family Health Survey, 1996 & $1994-1996$ & 37.0 \\
\hline 6 & NDHS, 2001 & $1998-2000$ & 33.5 \\
\hline 7 & NDHS, 2006 & $2003-2005$ & 28 \\
\hline 8 & NDHS, 2011 & $2008-2010$ & 24.3 \\
\hline 9 & NDHS, 2016 & 2016 & 22.4 \\
\hline 10 & WPP,2019 & 2019 & 20 \\
\hline
\end{tabular}

Source: CBS,2014, NDHS, 2006, 2011,2016, WPP 2019\& MoPE, 2017 
Total Fertility Rate (TFR): TFR is taken as one of the important measures of fertility highly influenced by socio-economic status and measured per woman. From the date of 1981 to 2019 it has been largely decreased from 6.27 to 1.9 per woman and seems decreasing rate among survey periods and it is around 2 from 2016 to 2019. It can be taken as an achievement from a policy point of view but if such a trend continues it will bring the situation of depopulation at coming future of the nation.

Table 2: Trends of Total Fertility Rate ( TFR, 1980/81-2019)

\begin{tabular}{|c|l|r|r|}
\hline S N & \multicolumn{1}{|c|}{ Sources } & Period/year & \multicolumn{1}{|c|}{ TFR } \\
\hline 1 & Nepal Contraceptive Prévalence Survey 1981, MOH & $1980-1981$ & 6.27 \\
\hline 2 & $\begin{array}{l}\text { Nepal Fertility and Family Planning Survey 1986, } \\
\text { MOH }\end{array}$ & $1984-86$ & 5.1 \\
\hline 3 & Nepal Family Health Survey 1996, MOH & $1993-95$ & 4.6 \\
\hline 4 & Nepal Demographic and Health Survey 2001, MOH & $1998-2000$ & 4.1 \\
\hline 5 & Nepal Demographic and Health Survey, 2006 & $2003-2005$ & 3.1 \\
\hline 6 & Nepal Demographic and Health Survey, 2011 & $2008-10$ & 2.6 \\
\hline 7 & Nepal Demographic and Health Survey, 2016 & 2016 & 2.3 \\
\hline 8 & Population Reference Bureau, 2018 & 2018 & 2.3 \\
\hline 9 & World Population Prospects, 2019 & $2015-20$ & 1.9 \\
\hline
\end{tabular}

Source: CBS 2014, NDHS 2016, WPP 2019, PRB 2018 \& MoPE, 2017

TFR by urban/rural and ecological zones: Total fertility rate (TFR) differs by many residential, socio-economic, cultural and geographical factors. Table 4 depicts that there is a large gap between the rural and urban places of residence in the context of TFR but which is in a decreasing trend. Urban TFR has been reduced from 2.9 to 1.54 and rural TFR 2.0 to 2.9 from 1994/96 to 2016. On the base of the ecological zone mountain zone have the highest TFR at all periods than hill and tarai. TFR has been decreased nearly by 50\% from 1994/96 to 2016 and it is nearly at replacement level, which may keep the population at a stable level at the near future.

Table 3: TFR by urban/rural and ecological zones (1994/96-2016)

\begin{tabular}{|l|r|r|r|r|r|r|}
\hline \multicolumn{1}{|c|}{ Year } & \multicolumn{2}{|c|}{ Urban/rural } & \multicolumn{3}{c|}{ Ecological zones } & \multirow{2}{*}{ Nepal } \\
\cline { 1 - 6 } & \multicolumn{1}{|c|}{ Urban } & \multicolumn{1}{c|}{ Rural } & Mountain & \multicolumn{1}{c|}{ Hill } & \multicolumn{1}{c|}{ Tarai } & \\
\hline $1994-96$ & 2.9 & 4.8 & 5.6 & 4.5 & 4.6 & \\
\hline 2001 & 2.92 & 4.75 & 4.39 & 3.21 & 3.17 & 3.25 \\
\hline 2011 & 1.54 & 3.08 & 3.73 & 2.45 & 2.46 & 2.52 \\
\hline 2016 & 2.0 & 2.9 & 3.0 & 2.1 & 2.5 & 2.3 \\
\hline
\end{tabular}

Source: NDHS 2011, $2016 \&$ MoPE, 2017 
Access and use of contraceptive: Use of family planning services and devices directly influences fertility and taken as one of the major tools for population management. Thirteenth periodic plan (2013/14-2015/16) and National Working Policy of Family Planning Services, 2068 have targeted used rate of family planning services up to $67 \%$ by the year 2015 but up to the year 2016 the rate is only $52.6 \%$. On the one, it has not been increased as expected way other, percentage of unmet need for contraception is nearly constant. Which is reduced from 27.7 to 23.7 in the period between 1991-2016. Table 5 shows level of met need and unmet need from 1991 to 2016 among currently married women aged 15-49. The result indicates that the percentage of met need has been more than doubled between the period 1991 to 2006 and up to 2016 it is $52.6 \%$. Similarly, the reduction of unmet need is 27.7 to 23.7 between the period 1991 to 2016 . It shows that the percentage of using contraception has not increased as target and expects of different plan and policies because the choice and use of contraception depends upon individual and couple's matters and societal culture. This low level of using contraceptives is controversial for a low level of fertility.

Table 4: Demand for contraceptives among currently married women aged 15-49, 1991-2016

\begin{tabular}{|c|r|r|r|}
\hline Year & $\begin{array}{c}\text { Unmet need for } \\
\text { contraception }\end{array}$ & $\begin{array}{c}\text { \% currently using } \\
\text { contraception (met need) }\end{array}$ & $\begin{array}{c}\text { Total demand for } \\
\text { contraception }\end{array}$ \\
\hline 1991 & 27.7 & 22.8 & 50.5 \\
\hline 1996 & 31.4 & 28.5 & 59.9 \\
\hline 2001 & 27.8 & 39.3 & 67.1 \\
\hline 2006 & 24.6 & 48.0 & 72.6 \\
\hline 2011 & 27 & 49.7 & 76.7 \\
\hline 2016 & 23.7 & 52.6 & 76.3 \\
\hline
\end{tabular}

Source: MoPE, $2017 \&$ NDHS, 2016

UN projection of some demographic indicators: Based on medium variant Un has projected basic demographic indicators up to the year 2100. Table 6 shows that the crude birth rate and total fertility rate will fall up to 7 per thousand and 1.69 per woman respectively in 2095-2100 but the sex ratio will remain constant as 107 males per 100 women for all years. Mean as of childbearing is in increasing trend and it will be 31 years until the period 2095-2100 indicates that fertility will fall sharply. The natural increase of population (birth-deaths) is estimated negative from the period 2070-2075 or deaths will exceed birth from that period. It shows needs to pay attention to population balance for the future. 
Table 5: UN projection of some demographic indicators, Nepal (2025-30 to 2095-2100)

\begin{tabular}{|l|r|r|r|r|}
\hline Indicators Periods AD & 2025-2030 & $\mathbf{2 0 4 5 - 2 0 5 0}$ & $\mathbf{2 0 7 0 - 2 0 7 5}$ & $\mathbf{2 0 9 5 - 2 1 0 0}$ \\
\hline $\begin{array}{l}\text { Crude birth rate per 1000 } \\
\text { population }\end{array}$ & 15.8 & 10.2 & 7.6 & 7.0 \\
\hline $\begin{array}{l}\text { Total fertility (live births per } \\
\text { woman) }\end{array}$ & 1.69 & 1.55 & 1.62 & 1.69 \\
\hline $\begin{array}{l}\text { Sex ratio at birth (males/100 } \\
\text { females) }\end{array}$ & 107 & 107 & 107 & 107 \\
\hline $\begin{array}{l}\text { Mean age of childbearing } \\
\text { (years) }\end{array}$ & 24.7 & 24.8 & 26.6 & 31.0 \\
\hline Number of births (thousands) & 2578 & 1805 & 1227 & 856 \\
\hline $\begin{array}{l}\text { Number of deaths } \\
\text { thousands) }\end{array}$ & 1560 & 1391 & 2144 & 2211 \\
\hline $\begin{array}{l}\text { Births minus deaths } \\
\text { thousands) }\end{array}$ & 413 & -917 & -1355 \\
\hline
\end{tabular}

Source: World Population Prospects, 2019

There is no doubt that family planning has significantly contributed to the area of population management. At the beginning time of the plan, there was no specific plans related to a population but the need for balancing between population and development was identified. Specific population-related goal and strategies were adopted at the sixth plan (1980-85) with the adoption of National Population Strategy (NPS) by the government in 1983. At the Eighth Plan (1992-97) Long Term plan in 1992 (19922000) introduced and NPS targets were revised. Policy and Workplan were guided by the International Conference on Population and Development (ICPD), 1994 from the Ninth Plan. Similarly, there remains the influence of MDGs on population policies in Nepal. Specific fertility reduction targets have been removed from the Fourteenth Plan but family planning is taken as a major tool to achieve the quality of life with widening its scope and area.

\section{Conclusion}

In the Nepalese context, the use of family planning services is increasing at a very slow rate but the total fertility rate is at around replacement level. There are other significant contributory socio-economic and cultural factors to determine fertility. It is necessary to adopt population responsive policy than the anti-natalist policy for the future. Population will be nearly stable in the context of Nepal after some years but the structure of a population will be changed due to transition, which will be challenging because of our slow pace of development and lacking appropriate population management policies. Utilization of a larger volume of active years population, management of internal and international migration-related appropriate 
policy on need base would favourable for sustainable socio-economic development of Nepal rather than fertility reduction. So, it is necessary to focus on management aspects as per the need of a nation rather than family planning and fertility reduction.

\section{References}

Dasgupta, S. (2012). Social demography. New Delhi: Dorling Kindersley Pvt.Ltd.

Demeny, Paul.(2003). Population policy: A Concise Summery. New York: Population Council, Policy Research Division, No. 173.

Dixit, R., \& Bandhani, A. (2019). Contraceptive knowledge, practices among women in Garhwal region. International Journal of Community Medicine and Public Health, 793-796.

MOH, New ERA, \& ICF. (2017). Nepal demographic and health survey 2016. Kathmandu, Nepal: Ministry of Health, Nepal.

MOHP, New ERA, \& ICF. (2012). Nepal Demographic and health survey 2011. Kathmandu, Nepal: Ministry of Health and Population, New ERA, and ICF International, Calverton, Maryland.

MoPE. (2016). National Population Report 2016. Kathmandu: Ministry of Population and Environment (MoPE).

MOPE. (2068). National population policy 2071. Kathmandu: Ministry of Population and Environment.

MOPE. (2068). Pariwar Niyojan Sewako Rastriya Karyaniti 2068. Kathmandu: Ministry of Population and Environment.

NPC. (2073). Fourteenth Plan (2016/17-2018/19). Government of Nepal, Kathmandu: National Planning Commission.

NPC. (2076). Fifteenth Plan Approach Paper (2076/77-2080/81), Government of Nepal, Kathmandu: National Planning Commission.

Organski, K. \& AFK Organski. (1961). Population and world power, Knopf: New York, USA

PRB. (2018). World Population Data Sheet. Washington DC: Population Reference Bureau.

Tuladhar, Jayanti Man. (1989). The Persistence of High Fertility in Nepal. New Delhi: Inter-India Publications.

United Nations, D. o. (2019). World Population Prospects 2019 Volume II: Demographic Profiles (ST/ESA/SER.A/427).

United Nations, D. o. (2019). World Population Prospects 2019 Volume II: Demographic Profiles (ST/ESA/SER.A/427).

United Nations, Department of Economic and Social Affairs, Population Division. (2019). World Population Prospects 2019: Data Booklet (ST/ESA/SER.A/424). 